\title{
Pengaruh Model Siklus Belajar Hipotesis-Deduktif terhadap Hasil Belajar Matematika Siswa SMA
}

\author{
*Helmi Rahmawati, Moh. Supratman, Zema Yuliana Aulan \\ Program Studi Pendidikan Matematika, Universitas Qamarul Huda Badaruddin, Turmuzi \\ Badrudin, Bagu Lombok Tengah 83371, Indonesia \\ *Email Korespondensi: helmirahmawati18@gmail.com
}

\begin{abstract}
Abstrak
Penelitian ini bertujuan untuk mendeskripsikan pengaruh model siklus belajar hipotesis-deduktif terhadap hasil belajar matematika siswa. Penelitian ini merupakan penelitian eksperimen semu dengan pretest-posttest control group design. Sampel penelitian ini melibatkan 66 siswa di dua kelas pada Madrasah Aliyah Darul Mahmudien NW Lombok Tengah sebagai sampel. Kelompok eksperimen (29 siswa) dan kelompok control (37 siswa) dipilih menggunakan teknik cluster random sampling. Data hasil belajar siswa dianalisis sesara statistic menggunakan independent t-test dengan bantuan software IBM SPSS versi 23. Hasil penelitian menunjukkan bahwa model siklus belajar hipotesis-deduktif berpengaruh signifikan $(p<0,05)$ terhadap hasil belajar matematika siswa. Temuan tersebut didukung hasil skor rata-rata kelompok eksperimen (mean=81,0345) yang lebih tinggi dari kelompok control (mean=76,9730) sehingga dapat disimpulkan bahwa model siklus belajar hipotesis-deduktif berpengaruh signifikan terhadap hasil belajar matematika siswa.
\end{abstract}

Kata kunci: siklus belajar; hipotesis-deduktif; hasil belajar

\section{The Effect of Hypothetical-Deductive Learning Cycle Model on Mathematics Learning Outcomes of High School Students}

\section{Abstract}

This study aims to describe the effect of the hypothetical-deductive learning cycle model on students' mathematics learning outcomes. This research is a quasi-experimental research with pretest-posttest control group design. The sample of this study involved 66 students in two classes at Madrasah Aliyah Darul Mahmudien NW Central Lombok as a sample. The experimental group (29 students) and the control group (37 students) were selected using cluster random sampling technique. Data on student learning outcomes were analyzed statistically using an independent $t$-test with the help of IBM SPSS version 23 software. The results showed that the hypothesis-deductive learning cycle model had a significant effect $(p<0.05)$ on students' mathematics learning outcomes. This finding is supported by the average score of the experimental group (mean $=81.0345$ ) which is higher than the control group (mean $=76.9730$ ) so it can be concluded that the hypothetical-deductive learning cycle model has a significant effect on students' mathematics learning outcomes.

Keywords: learning cycle; hypothetical-deductive; learning outcomes

How to Cite: Rahmawati, H., Supratman, M., \& Aulan, Z. Y. (2021). Pengaruh Model Siklus Belajar HipotesisDeduktif terhadap Hasil Belajar Matematika Siswa SMA. Empiricism Journal, 2(2), 85-94. https://doi.org/10.36312/ej.v2i2.599

https://doi.org/10.36312/ej.v2i2.599

\section{PENDAHULUAN}

Matematika merupakan kemampuan dasar yang sangat diperlukan siswa untuk bisa berhasil pada jengjang pendidikan lebih tinggi (Kuswanti dkk., 2017). Matematika mempunyai beberapa ciri penting, yaitu (1) memiliki objek yang abstrak berupa fakta, konsep, operasi dan prinsip yang berperan dalam membentuk proses pikiran matematis siswa; (2) memiliki pola pikir deduktif dan konsisten berupa seperangkat anggapan-anggapan yang tidak dipersoalkan lagi nilai kebenarannya dan dianggap benar yang berpangkal dari hal-hal yang bersifat umum dan diterapkan atau diarahkan pada hal-hal yang bersifat khusus; dan (3) konsisten dalam system yang bervariasi, ada sistem yang mempunyai kaitan satu sama lain, tetapi ada juga system yang dapat dipandang terlepas satu sama lain seperti sistem-sistem aljabar dan system-sistem geometri (Sriyanto, 2007). kompetensi inti kurikulum 2013 pada mata pelajaran 
matematika di jenjang pendidikan menengah menekankan siswa untuk mampu mengolah, menalar, dan menyaji dalam ranah konkrit dan ranah abstrak terkait materi belajar yang dipelajari secara mandiri, bertindak secara efektif dan kreatif, serta mampu menggunakan metode sesuai kaidah keilmuan (Kemendikbud, 2013).

Tuntutan kurikulum yang telah diuraikan tersebut nyatanya berbeda dengan hasil belajar matematika siswa. Hasil studi Trends in International Mathematics and Science Study (TIMSS) menunjukkan bahwa siswa Indonesia berada pada kategori rendah (Prastyo, 2020). Rata-rata kemampuan siswa hanya sebatas interpretasi diagram sederhana, melengkapi tabel sederhana, dan menerapkan pengetahuan dasar ke dalam situasi praktik. Padahal, kemampuan tingkat lanjut yang dikehendaki adalah siswa mampu memahami aspek dasar dan investigasi yang menuntut adanya identifikasi variabel, merancang investigasi, menggabungkan informasi untuk memprediksi dan menarik kesimpulan, menginterpretasikan informasi dalam bentuk diagram, peta, grafik, dan tabel untuk memecahkan masalah, serta mengkomunikasikan pengetahuan yang diperoleh melalui penjelasan tertulis (Martin dkk., 2012). Sejalan dengan pernyataan tersebut, hasil pra-penelitian menunjukkan bahwa hasil belajar matematika siswa di Madrasah Aliyah Darul Mahmudien NW Lombok Tengah tergolong rendah. Hal itu dibuktikan dengan banyaknya siswa yang mendapatkan hasil belajar matematika di bawah Kriteria Ketuntasan Minimal (KKM) (skor=75).

Permasalahan tersebut disinyalir terjadi karena beberapa factor seperti asumsi siswa yang menganggap matematika sebagai pelajaran yang sulit karena bersifat abstrak dan terdapat banyak rumus sehingga menyebabkan minat dan hasil belajar matematika siswa menjadi rendah (Salamah, 2020; Sari dkk., 2019). Selain factor tersebut, proses pembelajaran matematika juga diduga mempengaruhi hasil belajar matematika siswa (Sutama dkk., 2018). Dugaan tersebut sejalan dengan hasil wawancara di tempat penelitian bahwa proses pembelajaran matematika selama ini hanya menitik-beratkan pada penguasaan konsep tanpa melalui aktivitas-aktivitas yang memfasilitasi siswa untuk melakukan penalaran dan abstraksi matematis yang bermanfaat dalam membentuk keterampilan berpikir siswa. Upaya dyang dapat dilakukan untuk mengatasi permasalahan tersebut salah satunya dengan menerapkan pembelajaran yang sesuai dengan tuntutan kurikulum yang sebelumnya telah diuraikan.

Model siklus belajar hipotesis-deduktif merupakan model pembelajaran yang dapat diimplementasikan pada konteks tersebut. Model siklus belajar hipotesis-deduktif merupakan model pembelajaran yang berlandaskan pada pandangan konstruktivistik yang menekankan pada pembentukan pengetahuan secara mandiri (Dahar, 2003; Nur, 2011). Siswa dapam pembelajaran siklus belajar diminta mengawali pembelajaran dengan penyediaan pernyataan kausalistik (sebab-akibat), merumuskan kemungkinan pemecahan (hipotesis), memprediksi konsekuensi-konsekuensi logis dari hipotesis yang diajukan, merencanakan penyelesaian masalah (eksplorasi), menganalisis, dan menerapkan konsep secara kreatif (Lawson \& Karplus, 2002). Hasil penelitian sebelumnya menunjukkan dampak positif penggunaan model siklus belajar hipotesis-deduktif terhadap hasil siswa (Ramadoan \& Sulisworo, 2018). Respon siswa dan guru terhadap implementasi model hipotesis-deduktif juga menunjukkan respon yang positif (Saputra, 2019), namun belum ditemukan dampak atau implementasi model siklus belajar hipotesis-deduktif pada pembelajaran matematika. Penelitian ini bertujuan untuk mendeskripsikan pengaruh model siklus belajar hipotesis-deduktif terhadap hasil belajar siswa sekolah menengah.

\section{METODE}

Penelitian ini merupakan penelitian eksperimen semu dengan pretest-posttest control group design (Fraenkel dkk., 2012). Dua kelas di Madrasah Aliyah Darul Mahmudien NW Lombok Tengah (kelompok eksperimen $=29$ siswa, kelompok control= 36 siswa) yang dipilih menggunakan random sampling technique dijadikan sampel dalam penelitian ini. Secara sederhana desain penelitian disajikan pada Tabel 1.

Tabel 1. Desain penelitian

\begin{tabular}{cccc}
\hline Kelompok & Pretest & Perlakuan & Posttest \\
\hline Eksperimen & O1 & $X$ & O2 \\
Control & O3 & - & O4 \\
\hline
\end{tabular}


Di mana, (O1) adalah pretest untuk kelompok esperimen, $\mathrm{X}$ adalah perlakuan/pembelajaran menggunakan model siklus belajar hipotesis-deduktif pada kelompok eksperimen, (O2) adalah posttest kelompok eksperimen, (O3) adalah pretest kelompok control, (-) adalah perlakuan/pembelajaran menggunakan metode ceramah dan Tanya-jawab pada kelompok control, dan (O4) adalah posttest pada kelompok control.

Data hasil belajar siswa baik pretest ataupun posttest dikumpulkan menggunakan instrument tes berbentuk pilihan ganda berjumlah 20 item (Lampiran). Perbedaan hasil belajar siswa pada kelompok eksperimen dan kelompok kontrol ditentukan dengan menguji data hasil posttest siswa yang dianalisis secara statistic menggunakan independent sample t-test setelah memenuhi uji prasyarat distribusi data menggunakan one sample KolmogorovSmirnov test. Proses analisis dilakukan dengan bantuan software IBM SPSS versi 23.

\section{HASIL DAN PEMBAHASAN}

Data yang diperoleh dari implementasi model siklus belajar hipotesis-deduktif berupa data hasil belajar matematika siswa yang diberikan pada awal pembelajaran (pretest) dan setelah implementasi model siklus hipotesis-deduktif (posttest). Tabel 2 menunjukkan normalitas data pretest dan posttest hasil belajar matematika siswa pada kelompok eksperimen dan kelompok control. Uji normalitas data dilakukan menggunakan one sample Kolmogorov-Smirnov test sebelum melakukan uji perbedaan pengaruh perlakuan terhadap hasil belajar matematika siswa. Berdasarkan hasil analisis data, diketahui bahwa data pretest siswa tidak berdistribusi normal (sig. < 0,05) sedangkan data posttest siswa berdistribusi normal (sig. $>0,05$ ) sehingga independent sample t-test dilakukan untuk menguji pengaruh penggunaan model siklus belajar hipotesis-deduktif terhadap hassil belajar matematika siswa.

Table 2. Normalitas data pretest dan posttest hasil belajar siswa

\begin{tabular}{lllll}
\hline Tes & $\mathbf{N}$ & Std. Deviation & Sig. & Normalitas \\
\hline Pretest & 66 & 7.165 & 0.018 & Tidak \\
Posttest & 66 & 5.090 & 0.155 & Ya \\
\hline
\end{tabular}

Table 3 menunjukkan hasil uji perbedaan hasil belajar siswa pada kelompok eksperimen dan kelompok control. Hasil analisis menunjukkan terdapat perbedaan signifikan hasil belajar matematika siswa yang dibelajarkan menggunakan model siklus belajar hipotesis-deduktif ( $p$ $<0,05)$. Hasil analisis tersebut sejalan dengan perbedaan skor rata-rata hasil belajar siswa pada setiap kelompok, di mana skor rata-rata hasil belajar kelompok eksperimen (mean= 81,0345 ) lebih tinggi dari kelompok control (mean= 76,9730) sehingga dapat dinyatakan bahwa model siklus belajar hipotesis-deduktif berpengaruh signifikan terhadap hasil belajar matematika siswa.

Table 3. Hasil uji perbedaan hasil belajar siswa pada kelompok eksperimen dan kontrol

\begin{tabular}{lcccccc}
\hline Kelompok & $\mathbf{N}$ & Mean & $\begin{array}{c}\text { Std. } \\
\text { deviation }\end{array}$ & $\mathbf{t}$ & $\mathbf{d f}$ & $\mathbf{p}$ \\
\hline Eksperimen & 29 & 81.0345 & 5.12336 & 4.189 & 64 & 0.000 \\
Control & 37 & 76.9730 & 2.59793 & 3.895 & & \\
\hline
\end{tabular}

Hasil penelitian menunjukkan bahwa model siklus belajar hipotesis-deduktif berpengatuh signifikan terhadap hasil belajar matematika siswa. Hal ini disebabkan pembelajaran pembelajaran dalam model siklus belajar hipotesis-deduktif berorientasi pada konstruksi pengetahuan secara mandiri (Saputra, 2019). Sejalan dengan pernyataan tersebut, teori perkembangan kognitif meyakini pengetahuan diperoleh dari tindakan (Piaget, 1967) melalui keterlibatan aktif siswa pada tahapan-tahapan model siklus belajar hipotesis-deduktif seperti merencanakan penyelesaian masalah (eksplorasi), menganalisis, dan menerapkan konsep secara kreatif dengan memperhatikan interaksi social antar siswa (Vygotsky, 1981).

Siklus belajar hipotesis deduktif yang diawali dengan pengajuan pertanyaan untuk menggali atau mengeksplorasi pengetahuan awal siswa (Muhali \& Asy'ari, 2021) memberikan peluang bagi siswa untuk membangun pengetahuan sendiri (Haerunnissa dkk., 2019). Pembelajaran dengan pola seperti diuraikan tersebut dinyatakan sesuai dengan tuntutan pelaksanaan pembelajaran kurikulum 2013 yang berfokus pada kegiatan aktif siswa (Wasonowati dkk., 2014) untuk meningkatkan hasil belajar. Pengaruh positif model siklus 
belajar hipotesis-deduktif dalam penelitian ini didukung hasil-hasil penelitian terdahulu yang menemukan bahwa model siklus belajar hipotesis-deduktif efektif untuk meningkatkan penguasaan konsep (Dewi dkk., 2016) keterampilan berpikir kritis (Gunasih, 2011; Haerunnissa dkk., 2019), keterampilan generic sains (Muslimin dkk., 2019) dan hasil belajar siswa (Gunasih, 2011), namun penelitian-penelitian tersebut dilaksanakan pada mata pelajaran kimia dan fisika sehingga berbeda dengan penelitian ini yang dilaksanakan pada mata pelajaran matematikan pada siswa SMA.

\section{KESIMPULAN}

Penelitian ini telah mencapai tujuan yaitu mendeskripsikan pengaruh model siklus belajar hipotesis-deduktif terhadap hasil belajar matematika siswa. Hasil penelitian menunjukkan bahwa model siklus belajar hipotesis-deduktif berpengaruh signifikan terhadap hasil belajar siswa $(p<0,05)$ di mana berdasarkan tinjauan skor rata-rata hasil belajar matematika yang diperoleh, siswa pada kelompok eksperimen memiliki skor rata-rata (mean= $81,0345)$ lebih baik dari kelompok control (mean= 76,9730).

\section{REKOMENDASI}

Hasil penelitian ini telah membuktikan pengaruh model siklus belajar hipotesis-deduktif terhadap hasil belajar matematika siswa, namun penelitian ini hanya terbatas pada materi pertidaksamaan, sehingga perlu melakukan penelitian lebih lanjut pada materi-materi yang lain.

\section{DAFTAR PUSTAKA}

Dahar, R. W. (2003). Teori-teori belajar. Gelora Aksara Prima.

Dewi, R., Supriyanti, F. M. T., \& Dwiyanti, G. (2016). Analisis penguasaan konsep larutan elektrolit-nonelektrolit siswa menggunakan siklus belajar hipotesis deduktif. EduChemia (Jurnal Kimia dan Pendidikan), 1(2), 98-109. https://doi.org/10.30870/educhemia.v1i2.764

Fraenkel, J. R., Wallen, N. E., \& Hyun, H. H. (2012). How to design and evaluate research in education (8th ed). McGraw-Hill Humanities/Social Sciences/Languages.

Gunasih, N. L. M. A. (2011). Pengaruh penerapan model pembelajaran siklus belajar hipotesis - deduktif dengan seting 5 e (engagement-eksplorasi-ekslpanasi-elaborasi-evaluasi) terhadap keterampilan berpikir kritis dan hasil belajar fisika siswa (studi eksperimen di sma negeri 7 denp. Jurnal Pendidikan Dan Pembelajaran IPA Indonesia, 1(2), Article 2. https://ejournal-pasca.undiksha.ac.id/index.php/jurnal_ipa/article/view/246

Haerunnissa, N., Solfarina, S., \& Langitasari, I. (2019). Pengaruh Siklus Belajar Hipotesis Deduktif pada Konsep Reaksi Redoks Terhadap Keterampilan Berpikir Kritis. Jurnal Profesi Keguruan, 5(1), 31-37. https://doi.org/10.15294/jpk.v5i1.17783

Kemendikbud. (2013). Peraturan Menteri Pendidikan dan Kebudayaan Republik Indonesia Nomor $54 \quad$ Tahun $2013 . \quad$ Kemendikbud. https://akhmadsudrajat.files.wordpress.com/2013/06/01-b-salinan-lampiranpermendikbud-no-54-tahun-2013-ttg-skl.pdf

Kuswanti, Y., Setiawani, S., \& Lestari, N. D. S. (2017). Analisis Soal Dalam Buku Siswa Matematika Kurikulum 2013 Untuk Sekolah Menengah Pertama Kelas VII Berdasarkan Dimensi Kognitif Trends International Mathematics and Science Study (TIMSS). Jurnal Edukasi, 4(3), 25. https://doi.org/10.19184/jukasi.v4i3.6156

Lawson, A. E., \& Karplus, R. (2002). The Learning Cycle. Dalam R. G. Fuller (Ed.), A Love of Discovery (hlm. 51-76). Springer Netherlands. https://doi.org/10.1007/978-94-0070876-1_4

Martin, M. O., Mullis, I. V. S., Foy, P., Stanco, G. M., International Association for the Evaluation of Educational Achievement, \& Trends in International Mathematics and Science Study (Ed.). (2012). TIMSS 2011 international results in science. IEA, TIMSS \& PIRLS, International Study Center, Lynch School of Education, Boston College.

Muhali, M., \& Asy'ari, M. (2021). Penerapan Pendekatan STML dengan Strategi Siklus Belajar Empiris-Induktif untuk Meningkatkan Hasil Belajar dan Literasi Sains-Teknologi Siswa. Empiricism Journal, 2(1), 1-9. https://doi.org/10.36312/ej.v2i1.473 
Muslimin, M., Yoga, W., \& Darmadi, W. (2019). Pengaruh Model Siklus Belajar Hipotetikal Deduktif terhadap Keterampilan Generik Sains Siswa Kelas X di SMA Negeri 1 Balaesang pada Mata Pelajaran Fisika. JPFT (Jurnal Pendidikan Fisika Tadulako Online), 6(3), 40-44.

Nur, M. (2011). Modul Keterampilan-keterampilan Proses dan Hakikat Sains. PSMS Unesa.

Piaget, J. (1967). Six Psychological Studies. Random House.

Prastyo, H. (2020). Kemampuan Matematika Siswa Indonesia Berdasarkan TIMSS. Jurnal Padegogik, 3(2), 111-117. https://doi.org/10.35974/jpd.v3i2.2367

Ramadoan, N., \& Sulisworo, D. (2018). Strategi berpikir hipotetikal deduktif dalam pengembangan keterampilan berpikir kritis pada pembelajaran fisika. Quantum: Seminar Nasional Fisika, Dan Pendidikan Fisika, 0, 351-357.

Salamah, D. P. (2020). Analisis kesalahan berdasarkan newman error analysis terhadap materi peluang kejadian majemuk ditinjau dari gender dan self confidence pada siswa kelas xii smk di Bandung Barat. JPMI (Jurnal Pembelajaran Matematika Inovatif), 3(4), 273-284. https://doi.org/10.22460/jpmi.v3i4.p\%p

Saputra, H. N. (2019). Analisis respon guru dan siswa terhadap penerapan model siklus belajar hipotesis deduktif dalam pembelajaran kimia. PEDAGOGIK: Jurnal Pendidikan, 6(2), 278-299. https://doi.org/10.33650/pjp.v6i2.729

Sari, N. R., Hidayat, W., \& Yuliani, A. (2019). Analisis Hasil Belajar Matematika Siswa Kelas $X$ SMA Pada Materi SPLTV Ditinjau Dari Self-Efficacy. UNION: Jurnal IImiah Pendidikan Matematika, 7(1), 93-104. https://doi.org/10.30738/union.v7i1.3776

Sriyanto. (2007). Startegi Sukses Menguasai Matematika. Indonesia Cerdas.

Sutama, S., Janah, N. N., \& Novitasari, M. (2018). Faktor Stratejik Hasil Belajar Matematika Siswa di Sekolah Menegah Pertama. Jurnal VARIDIKA, 29(2), 176-184. https://doi.org/10.23917/varidika.v29i2.5633

Vygotsky, L. S. (1981). Mind in society: The development of higher psychological processes (Nachdr.). Harvard Univ. Press.

Wasonowati, R. R. T., Redjeki, T., \& Ariani, S. R. D. (2014). Penerapan model problem based learning (pbl) pada pembelajaran hukum - hukum dasar kimia ditinjau dari aktivitas dan hasil belajar siswa kelas x ipa sma negeri 2 Surakarta tahun pelajaran 2013/2014. Jurnal Pendidikan Kimia, 3(3), 66-75. 


\section{Lampiran \\ Instrument penelitian}

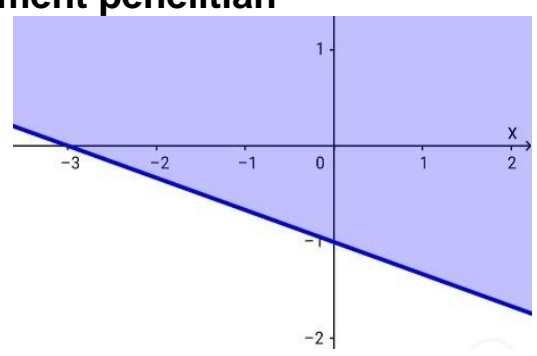

1. Daerah yang diarsir merupakan penyelesaian dari pertidaksamaan.....
A. $3 Y+x \geq-3$
B. $3 y+x \leq-3$
C. $3 y+x \leq 3$
D. $3 y-x \leq 3$
E. $3 X+y \geq-3$

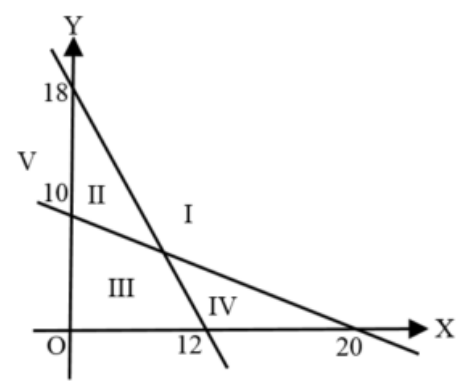

2. Daerah penyelesaian dari sistem pertidaksamaan $3 x+2 y \leq 36 ; x+2 y \geq 20 ; x \geq 0$ dan $y \geq 0$ pada gambar di atas adalah $\ldots .$.
A. $V$
C. III
E. I
B. IV
D. II

3. Sistem pertidaksamaan linear untuk daerah yang diarsir pada gambar di bawah adalah ....

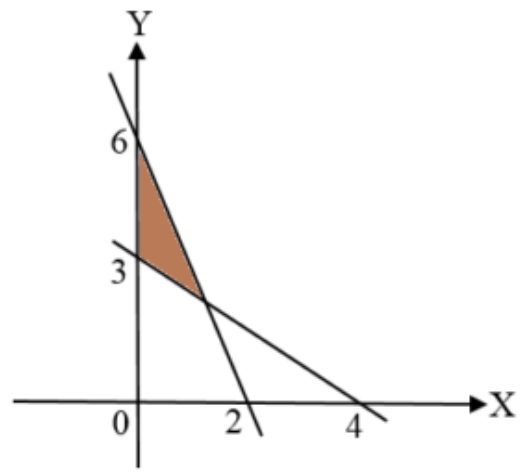
A. $3 x+4 y \geq 12 ; 3 x+y \leq 6 ; x \geq 0 ; y \geq 0$
B. $3 x+4 y \leq 12 ; 3 x+y \geq 6 ; x \geq 0 ; y \geq 0$
C. $3 x+4 y \geq 12 ; x+y \leq 6 ; x \leq 0 ; y \geq 0$
D. $3 x+4 y \leq 12 ; 3 x+y \leq 6 ; x \geq 0 ; y \geq 0$
E. $3 x+4 y \geq 12 ; 3 x+y \geq 6 ; x \geq 0 ; y \geq 0$

4. Daerah penyelesaian yang memenuhi system pertidaksamaan $x \geq 2 ; y \leq 8, x-y \leq 2$ berbentuk.....

A. segitiga lancip

B. segitiga sama sisi 

C. segitiga sebarang
D. segitiga tumpul sama kaki
E. segitiga siku-siku sama kaki

5. Perhatikan gambar berikut ini.

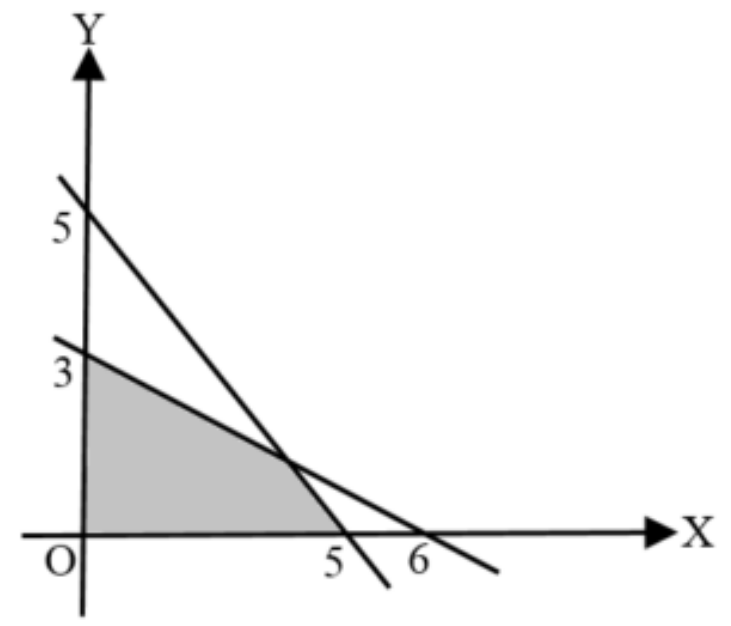

Nilai maksimum untuk fungsi objektif $P=3 x+5 y$ adalah $\ldots .$.
A. 15
C. 17
E. 19
B. 16
D. 18

6. Perhatikan grafik berikut.

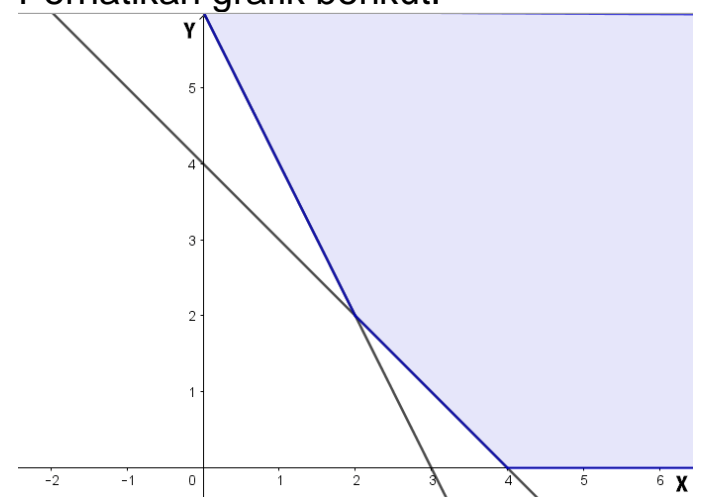

Nilai minimum dari $Z=2 x+5 y$ dari daerah yang diarsir adalah $\ldots .$.
A. 6
C. 10
E. 14
B. 8
D. 11

7. Nilai maksimum fungsi objektif $f(x, y)=4 x+5 y$ yang memenuhi sistem pertidaksamaan $x+2 y \geq 6 ; x+y \leq 8 ; x \geq 0 ; y \geq 2$ adalah $\cdots$.
A. 15
C. 34
E. 42
B. 18
D. 40

8. Anis akan membeli mangga dan apel. Jumlah buah yang dibeli paling sedikit 12 buah. Mangga yang dibeli paling banyak 6 buah. Harga mangga Rp2.000,00 per buah dan apel Rp4.000,00 per buah. la mempunyai uang Rp20.000,00. Jika ia membeli $x$ mangga dan y apel, maka sistem pertidaksamaan yang sesuai adalah ....
A. $x+2 y \geq 10 ; x+y \geq 12 ; x \geq 6$
B. $x+2 y \leq 10 ; x+y \geq 12 ; x \leq 6$
C. $x+2 y \leq 10 ; x+y \leq 12 ; x \geq 6$
D. $x+2 y \leq 10 ; x+y \geq 12 ; x \geq 6$
E. $x+2 y \geq 10 ; x+y \geq 12 ; x \leq 6$

9. Nilai maksimum dan minimum fungsi $z=4 x+3 y$ yang memenuhi system pertidaksamaan $x+y \leq 6,2 x+y \geq 3, x \geq 1, x \leq 4$ dan $y \geq 0$ adalah...
A. 7 dan 22
B. 6 dan 22 

C. 6 dan 24
D. 7 dan 24
E. 6 dan 20

10. Nilai maksimum dari $f(x, y)=2 x+3 y$ pada daerah $3 x+y \geq 9,3 x+2 y \leq 12, x \geq 0$ dan $y \geq 0$ adalah....
A. 6
B. 12
C. 13
D. 18
E. 27

11. Luas sebuah tempat parkir adalah $420 \mathrm{~m} 2$. Tempat parkir yang diperlukan oleh sebuah sedan adalah $5 \mathrm{~m} 2$ dan luas rata-rata sebuah truk $15 \mathrm{~m} 2$. Tempat parkir tersebut dapat menampung tidak lebih dari 60 kendaraan. Biaya parkir untuk sebuah sedan Rp3.000,00 dan untuk sebuah truk Rp5.000,00. Jika banyak sedan yang diparkir $\mathrm{x}$ buah dan banyak truk y buah, model matematika dari masalah tersebut adalah...
A. $x+3 y \leq 84 ; x+y \leq 60 ; x \geq 0 ; y \geq 0$
B. $x+3 y \geq 84 ; x+y \leq 60 ; x \geq 0 ; y \geq 0$
C. $x+3 y \leq 84 ; x+y \geq 60 ; x \geq 0 ; y \geq 0$
D. $x+3 y \geq 84 ; x+y \geq 60 ; x \geq 0 ; y \geq 0$
E. $3 x+y \leq 84 ; x+y \leq 60 ; x \geq 0 ; y \geq 0$

12. Nilai maksimum $f(x, y)=5 x+4 y$ yang memenuhi pertidaksamaan $x+y \leq 8, x+2 y \leq$ $12, x \geq 0, y \geq 0$ adalah.....
A. 32
B. 24
C. 36
D. 40
E. 60

13. Nilai maksimu $f(x, y)=5 x+7 y$ yang memenuhi system pertidaksamaan $2 x+3 y \leq 12$, $x+2 y \leq 8, x \geq 0, y \geq 0$ adalah....
A. 29
B. 28
C. 31
D. 30
E. 32

14. Seorang anak diharuskan minum dua jenis tablet setiap hari. Tablet jenis I mengandung 5 unit vitamin A dan 3 unit vitamin $B$. Tablet jenis II mengandung 10 unit vitamin $A$ dan 1 unit vitamin $B$. Dalam 1 hari, anak tersebut memerlukan 25 vitamin A dan 5 unit vitamin B. Jika harga tablet I Rp4.000,00 per butir dan tablet II Rp8.000,00 per butir, maka pengeluaran minimum untuk pembelian tablet per hari adalah ....
A. Rp6.000,00
B. Rp6.700,00
C. $R p 7.000,00$
D. Rp20.000,00
E. Rp22.000,00

15. Seorang penjahit memiliki persediaan $20 \mathrm{~m}$ kain polos dan $20 \mathrm{~m}$ kain bergaris untuk membuat 2 jenis pakaian. Pakaian model 1 memerlukan $1 \mathrm{~m}$ kain polos dan $3 \mathrm{~m}$ kain bergaris. Pakaian model II memerlukan $2 \mathrm{~m}$ kain polos dan $1 \mathrm{~m}$ kain bergaris.

Pakaian model I dijual dengan harga Rp150.000,00 per potong dan pakaian model II dijual dengan harga Rp100.000,00 per potong. Penghasilan maksimum yang dapat diperoleh penjahit tersebut adalah ....
A. Rp1.400.000,00 

B. Rp1.600.000,00
C. Rp1.800.000,00
D. Rp1.900.000,00
E. Rp2.000.000,00

16. Seorang pengusaha roti akan membuat roti. Roti jenis I membutuhkan 20 gram tepung dan 10 gram mentega, sedangkan roti jenis II membutuhkan 15 gram tepung dan 10 gram mentega. Bahan yang tersedia adalah tepung $5 \mathrm{~kg}$ dan mentega $4 \mathrm{~kg}$. Jika x menyatakan banyaknya roti jenis I dan y menyatakan banyaknya jenis roti II, model matematika persoalan tersebut adalah ....

F. $4 x+3 y \geq 1000 ; x+y \geq 400 ; x \geq 0 ; y \geq 0$

G. $4 x+3 y \geq 1000 ; x+y \leq 400 ; x \geq 0 ; y \geq 0$

H. $4 x+3 y \leq 1000 ; x+y \geq 400 ; x \geq 0 ; y \leq 0$

I. $4 x+3 y \leq 1000 ; x+y \leq 400 ; x \geq 0 ; y \geq 0$

J. $4 x+3 y \geq 1000 ; x+y \geq 400 ; x \leq 0 ; y \leq 0$

17. Pemerintah akan mengirim bantuan logistik minimal berupa 100 peti makanan dan 84 peti obat-obatan menggunakan 2 jenis kendaraan, yaitu helikopter dan truk. Helikopter dapat mengangkut 10 peti makanan dan 14 peti obat-obatan. Truk dapat mengangkut 10 peti makanan dan 6 peti obat-obatan. Jika biaya operasional pengiriman menggunakan helikopter adalah Rp2.500.000,00 dan truk Rp1.500.000,00 sekali jalan, maka biaya minimum untuk mengangkut seluruh bantuan logistik adalah ....
A. Rp10.000.000,00
B. Rp12.000.000,00
C. $R p 18.000 .000,00$
D. Rp21.000.000,00
E. Rp25.000.000,00

18. Pak Alim memiliki lahan pertanian seluas 8 hektare. la akan menanami lahan tersebut dengan tanaman padi dan jagung. Dari satu hektare lahan yang ditanam padi dapat dipanen 3 ton padi, sedangkan dari satu hektare lahan yang ditanam jagung dapat dipanen 4 ton jagung. Pak Alim ingin memperoleh hasil panen tidak kurang dari 30 ton. Jika biaya menanam padi pada 1 hektare lahan adalah Rp500.000,00 dan biaya menanam jagung pada 1 hektare lahan adalah Rp600.000,00, maka biaya minimum yang harus dikeluarkan Pak Alim adalah ....
A. Rp5.500.000,00
B. Rp5.000.000,00
C. $\operatorname{Rp} 4.800 .000,00$
D. Rp4.500.000,00
E. Rp4.200.000,00

19. Seorang perajin tas membuat dua jenis tas. Sebuah tas jenis I memerlukan $300 \mathrm{~cm} 2$ kulit sintetis dan $1.000 \mathrm{~cm} 2$ kain kanvas, sedangkan sebuah tas jenis II memerlukan $250 \mathrm{~cm} 2$ kulit sintetis dan $500 \mathrm{~cm} 2$ kain kanvas. Persediaan kulit sintetis dan kain kanvas berturut-turut adalah $4.500 \mathrm{~cm} 2$ dan $12.000 \mathrm{~cm} 2$.

Perajin tas menginginkan laba dari penjualan tas jenis I dan tas jenis II berturut-turut sebesar Rp30.000,00 dan Rp25.000,00 per buah. Jika seluruh tas terjual, laba maksimum yang dapat diperoleh perajin tas adalah ....
A. Rp360.000,00
B. $R p 435.000,00$
C. $R p 450.000,00$
D. $R p 540.000,00$
E. Rp630.000,00

20. Seorang pedagang kopi akan membuat kopi campuran dengan cara mencampur kopi toraja dan kopi flores. Kopi campuran yang pertama terdiri dari $4 \mathrm{~kg}$ kopi toraja dan 6 kg kopi flores, sedangkan kopi campuran yang kedua terdiri dari 8 kg kopi toraja dan $2 \mathrm{~kg}$ kopi flores. Kopi yang tersedia untuk kopi toraja dan kopi flores berturut-turut adalah 48 ton dan 54 ton. Jika harga jual kopi campuran pertama adalah Rp80.000,00/kg dan harga jual kopi campuran kedua adalah 
Rp100.000,00/kg, maka penjualan maksimum yang diperoleh sebesar ....
A. Rp600.000.000,00
B. $R p 720.000 .000,00$
C. Rp852.000.000,00
D. Rp900.000.000,00
E. Rp974.000.000,00 